\title{
A Resource-Based View and Institutional Theory- based analysis of Industry 4.0 Implementation in the Indian Engineering Industry
}

\author{
Michael Sony ${ }^{1} \&$ P. S. Aithal ${ }^{2}$ \\ ${ }^{1}$ Post-Doctoral Researcher, College of Engineering \& Technology, Srinivas University, Mangalore \\ 575001 , India \\ Email: emailofsony@gmail.com \\ ${ }^{2}$ ViceChancellor, Srinivas University, Mangalore, India, \\ E-Mail: psaithal@gmail.com
}

Area/Section: Industrial Engineering.

Type of the Paper: Conceptual Analysis.

Type of Review: Peer Reviewed as per $|\mathrm{C}| \mathrm{O}|\mathrm{P}| \mathrm{E} \mid$ guidance.

Indexed in: OpenAIRE.

DOI: http://doi.org/10.5281/zenodo.4037809

Google Scholar Citation: IJMTS.

\section{How to Cite this Paper:}

Sony., Michael, \& Aithal, P. S. (2020). A Resource-Based View and Institutional Theory-based analysis of Industry 4.0 Implementation in the Indian Engineering Industry. International Journal of Management, Technology, and Social Sciences (IJMTS), 5(2), 154-166.

DOI: http://doi.org/10.5281/zenodo.4037809

International Journal of Management, Technology, and Social Sciences (IJMTS)

A Refereed International Journal of Srinivas University, India.

(c) With Authors.

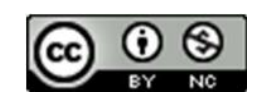

This work is licensed under a Creative Commons Attribution-Non-Commercial 4.0 International License subject to proper citation to the publication source of the work.

Disclaimer: The scholarly papers as reviewed and published by the Srinivas Publications (S.P.), India are the views and opinions of their respective authors and are not the views or opinions of the SP. The SP disclaims of any harm or loss caused due to the published content to any party. 


\title{
A Resource-Based View and Institutional Theory-based analysis of Industry 4.0 Implementation in the Indian Engineering Industry
}

\author{
Michael Sony ${ }^{1} \&$ P. S. Aithal ${ }^{2}$ \\ ${ }^{1}$ Post-Doctoral Researcher, College of Engineering \& Technology, Srinivas University, Mangalore \\ 575001 , India \\ Email: emailofsony@gmail.com \\ ${ }^{2}$ ViceChancellor, Srinivas University, Mangalore, India, \\ E-Mail: psaithal@gmail.com
}

\begin{abstract}
Industry 4.0 is the digital transformation of the organization to meet the organizational goals and objectives. Industry 4.0 is making slow inroads in the Indian Engineering Industry. Therefore, there is a need for a study to understand the dynamics of the implementation in Indian Engineering Industry from a theoretical point of view. This study uses the Institutional Theory and ResourceBased theory to analyse the implementation of Industry 4.0. "Coercive", "normative" and "mimetic" pressure is used to analyse the forces on firms to implement Industry 4.0. Resource-based view is further used to analyse how the "physical, human, organizational, technological, financial and reputational capital" can be used in Indian Engineering Industry to attain competitive advantage. The study also develops a model to understand the dynamics of Industry 4.0 implementation. This is the first study to analyse the dynamics of Industry 4.0 implementation in Indian Engineering Industry. It will help the academicians to enrich the theoretical base of Industry 4.0 implementation. The industry will benefit from this analysis to understand the decision-making process for the implementation of Industry 4.0. The study can be used by the Government to decide policies that formal, informal rules and policies will help the Industries to implement Industry 4.0.
\end{abstract}

Keywords: Industry 4.0, Indian Engineering Industry, Institutional Theory, Resource-Based Theory, Industry 4.0 Implementation.

\section{INTRODUCTION :}

Industry 4.0 implementation in firms have changed their strategy, business models, supply chains, value chains, customers, skills, stakeholders, etc [1]. Industry 4.0 changes long term relationships between a) "organization and Nature" b) "organization and local communities" c) "organization and value chains" d) "organization and humans" $[2,3]$. These changes in the relationship of the firm with various stakeholders can create new opportunities as well as it can also result in vulnerabilities in societies such as unemployment, as most of the jobs would be done by machines and whatever, jobs remain will be higher-order jobs [4]. Therefore, the Governments around the world are creating awareness for sustainable implementation of Industry 4.0 by considering the pluralism [1]. Industry 4.0 can be thought as a methodology wherein the manufacturing which was dominated by machines, will now be dominated by digital manufacturing. In other words, it is the holistic digital transformation of the organization by "vertical", "horizontal" and "end-to-end" integration of various systems within and external to the organization $[5,6]$. From the first industrial revolution, there is a need to produce more products by using limited natural resources as the demand is ever increasing. Besides, the negative externalities of the increased production process have to be minimised so that the world will be a better place to live for future generations [7, 8]. In Industry 4.0 there is the 
interconnectivity of machines and other functional systems of the organization using digital technologies such as "Internet of things (IoT)", "Cyber Physical Systems (CPS)", and "Cloud Computing". There will minimal human interaction and maximisation of automation. Implementation of Industry 4.0 will increase manufacturing productivity, waste reduction, and resource efficiency[9]. Industry 4.0 implementation will result in (a) "Business model novelty and innovation" (b) "Carbon/harmful gas emission reduction" (c) "Corporate profitability improvement" (d) "Economic development" e) "Energy and resource sustainability" (f) "Environmental responsibility development" (g) "Human resource development" (h) "Increased production efficiency and productivity" (i) “ Job creation" (j) “ Manufacturing cost reduction" (k) "Manufacturing agility and flexibility" (1) "Production modularity" (m) " Product personalization" (n) "Risk and safety management" (o) "Supply chain digitization and integration" and (p) "Social welfare enhancement" [8]. In India Industry 4.0 is making gradual inroads[10]. The "United Nations Industrial Development Organization (UNIDO)" posits that among the 10 global front runners in Industry 4.0, India is the only middle-income country which is rapidly transforming its production units using Advanced Digital Production( ADP) [11]. The "SAMARTH Udyog Bharat 4.0" an initiative from the "Government of India" is a strategic initiative in this regard. This programme by the Government of India is to help Industries to use to the advanced technologies of Industry 4.0 to make products and services which can be sold in the global markets [12]. The application of Industry 4.0 in the "Indian engineering sector" will yield better results, as it has seen incredible growth in exports over recent years. To be a global superpower "Government of India" has appointed "Engineering export promotion council (EEPC)". The Indian Engineering Industries represent the biggest segment in the Indian Industry. It is also India's largest foreign exchange earner, as it contributes to $25 \%$ to Indian total exports in goods. It further has $30 \%$ weight in India's "Index of Industrial Production" [13]. Industry 4.0 implementation in the Indian Engineering Sector is in still infancy [13]. Hence, for wider adoption of Industry 4.0 in there is a need for research to develop business models, management systems in addition to the technological base of the Industry 4.0 [14]. Industry 4.0 implementation decision in Indian Engineering Industry is a dynamic process and therefore there is a need to analyse the decision-making process of Industry 4.0. The research on Industry 4.0 implementation models are lacking in Indian Engineering Industry, therefore, a theoretical study is proposed using resource-based view and Institutional Theory to analyse the implementation of Industry 4.0. The remainder of the paper is organized as follows, the next section is devoted to background information, followed by theoretical analysis, integrated model development, discussion and conclusion.

\section{BACKGROUND INFORMATION :}

\subsection{Institutional Theory}

Institutional theory professes that firm operates within a social framework which is made up of norms, culture, values, taken for granted assumptions which determines what is appropriate and what is not appropriate for the firm [15]. Human behaviours usually extend beyond economic optimization to social justification and social obligation [16]. Organizations usually base their decision on social norms and conformity to social norms are means of success for the organization [17]. The two divisions of the institutional theory are the ones which are focussed on internal organizational dynamics ("micro-sociological approach") and the ones which are focused on the firm behaviour and wider societal realities ("macro-level socio-economic approaches")[18, 19]. Institutional theory is a study of the response of an organization in response to external disturbances. One of the central tenants of the assumption of institutional theory is that individuals are motivated to comply with social pressures. External forces help to build organizational resources to create organizational capability. Organizational legitimacy is the degree of alignment of the subject within the context of the social system and is the primary need for structural and behavioural changes in the organizations. The motivation of legitimacy makes the organization to embrace institutionalization. This makes organizations almost similar to each other and not necessarily it is targeted to making it more efficient "Institutional isomorphism" [20]. The institutional environment has three components (1) regulatory, (2) cognitive, and (3) normative environment and these are motivated by coercive, mimetic, and normative 
mechanisms, respectively [21].

\subsubsection{Coercive Pressure}

This is due to regulations \& policies from the government, industry and other professional associations or a minimum competition criterion within an Industry or market segment [19]. It is also due to pressures exerted by other organization depended on by the organization under consideration in a coercive manner. Social pressures also will help to influence the selection of safe technology, rather than just economic incentive [22]. It could also be pressures from the political, social, legal influence of the environment where the firm operates.

\subsubsection{Normative pressure}

This is the pressure created by the professionalization of the organization. The professionalization is created by a pool of employees who are educated and trained who are willing to adopt technology[22]. Organizations will adopt new technology to maintain good relationships with other organizations so that the culture of cooperation is maintained. Thus, normative pressure is responsible to select and apply new technology [20].

\subsubsection{Mimetic pressure}

This is due to the organization's tendency to mimic other organization and this is because of poor understanding of technologies and direction. Organizations usually mimic other organizations who they perceive to be successful [23].

\subsection{Updated View of Institutional Theory}

The institutionalization can be defined as a "social process by which individuals come to accept a shared definition of social reality" [21]. The seminal work of Grewal and Dharwadkar (2002) explicates three processes a) regulating (b) validating and (c) habitualising [24]. Regulating process is the interaction with various regulating institutions within the society, which is designed for creating stability, continuity, and order in societies. The regulatory agencies may control the organization through inducement and imposition. This is almost same as the coercive pressure. In imposition, the channel members use the coercive power for larger societal good to regulate the actions which conflict. When channel members actions conflict with the societal good, societal institutions are formed to force channel members, so that the goal of societal good is attained. These societal institutions will interpret the standards for the societal good and use the authority to coerce the institutions to adhere to developed standards so that societal good is achieved. These standards may rest on economic efficiency, but neoclassical theories suggest it may in turn meet the social good [25]. The response of channel members will generally be of two types: (a) resisting or (b) Accepting. The channel members usually resist these standards and make some cosmetic changes, till the time these standards are enacted as laws [26]. In inducement the societal institution may not have the power vested in them to impose actions, rather they try to induce the channel members to follow the set standards, for societal good. One way of inducement is giving incentives or disincentives for channel members who follow or does not follow the set standards of these societal institutions for social good.

The second process is validating, and it can be described as interactions between old normative and mimetic pressure. The normative process can be thought of authorising and acquisition. Authorization is the development of codes or rules which are developed as a need of the hour. These developed code or rules require authorisation by respective authorising bodies e.g. trade unions, government regulators. The acquisition is mimicking other organizations to achieve legitimacy. This will result in organizations mimicking without understanding the means effect- relationships. The third institutionalization process is habitualising is a base-level process where actions which are repeated overtime period will become an action. These actions are repeated with minimal efforts. There are two sub-processes of habitualising (a) imprinting and bypassing. Both of them is directed towards two things "programmed actions" or "common responses to similar situations". Imprinting retains or maintains structure and processes that were made in the early years of organizational development. Bypassing involves cultural norms or shared beliefs which have developed over the years and have substituted for formal control and coordination mechanisms.

\subsection{Resource-Based Theory}


The resource-based view emphasises the importance of strategically used firms internal resources which are "valuable", "heterogeneous", "immobile", and "inimitable resources" to create a competitive advantage [2729]. The resources are of two types tangible or intangible. Tangible resources are assets, machines etc and intangible resources such as organizational learning, organizational knowledge, intellectual capital, staff skills, etc[28]. The firms can use these resources in an inimitable manner to create a competitive advantage [30]. The resources are classified as human capital, physical capital, and organizational capital [31]. The resources were further extended to technological, financial, and reputational capital. These resources are difficult to acquire because diverse firms will have different capabilities in these resources. Firms can bundle these resources in a complex combination to create a competitive advantage [32]. Another concept is complementarity, where one resource will influence another resource to create a unique competitive position [33]. Therefore, this unique resource position created by the firm will be extremely difficult to imitate by the rival competitive firms. Hence, internal resources can be used strategically to implement Industry 4.0

\section{THEORETICAL ANALYSIS :}

\subsection{Institutional Theory and Industry 4.0 in Indian Engineering Industries}

Industry 4.0 aims to develop and sustain the dynamic capabilities of the firms using technologies such as (1) IoT, (2) CPS, and (3) Cloud computing. The digital transformation of the firm helps in attaining the competitive advantage by either efficiently using existing resources or using these new technologies to enter novel ways of doing the business. The firm also can compete in dimensions such as cost, quality, timeliness, flexibility, and delivery channels due to the implementation of Industry 4.0 [34, 35]. Industry 4.0 is making a gradual entry into Indian organizations. Indian Engineering Industry which is the largest segment in the Indian Industry will benefit due to the implementation of Industry 4.0. However, the implementation of Industry 4.0 has been dismally poor in the Indian Engineering Industry [10]. Institutional Theory analysis of Industry 4.0 on Indian Engineering Industry will help to understand and take measures so that more and more Indian Engineering Industries will be able to implement Industry 4.0. The coercive pressure for implementation of Industry 4.0 in Indian Engineering Industry has been multi-dimensional. The Government of India is trying their best so that Indian Engineering Industry adopts Industry 4.0 [13]. Department of Heavy Industries has done a laudable work to popularise practical Industry 4.0 solutions through "Smart Advanced Manufacturing and Rapid Transformation Hub (SAMARTH)- Udyog Bharat 4.0" [36]. Indian Engineering Industry accounts for $25 \%$ of total exports of India. To be competitive in the global markets is the implementation of Industry 4.0. In the last decade, it is seen that India's stake in the "global engineering trade" is around $1.2 \%$ compared to China's $12 \%$. Besides India does not possess any "dominant position" in any of the 34-product category defined by DGCIS classification and is termed as "follower" nation. India is trying to achieve a dominant position, in some product categories in the next five years. In the overall Engineering export basket, only $6 \%$ is constituted "high tech goods", others were "low and medium technology goods". The reduction in high tech industries is due to the fact all exporters relied on labour cost arbitrage [13]. However, this is not sustainable in the long run, as emerging concepts around the world like "nearshoring" and "disruptive technologies" will break the advantage in the long run. Therefore, there is immense pressure from the Industry and global markets for the implementation of Industry 4.0. Implementing Industry 4.0 will help in making the international trade paperless, hassle-free and fast thereby giving a scope of international trade at a reduced cost. This is possible if Industry 4.0 is implemented fully so that harmonization of cross border data transfer, protocols, competitive condition, privacy are given adequate representation in the Industry 4.0 implementation framework [37]. Industry 4.0 is popular and implemented by manufacturers in Europe and America, and if the Indian Engineering Industry must compete or cooperate with them in the international trade there is pressure towards the implementation of Industry 4.0. Industry 4.0 due to real-time monitoring of the processes and products through big data analytics makes the product safe [38], workplace ergonomically appropriate[39], and organizational environmentally safe due to reduced emissions [40]. Therefore, there is a pressure created by the society towards Indian Engineering Industry to implement Industry 4.0 
The normative pressure is created for the implementation of Industry 4.0 in the Indian Engineering Industry. "Supply chain" is perennial for the success of an organization in terms of its achieving organizational goals such as reducing cost and increasing organizational profits [41]. The success of supply chain operations depends on how well the systems, processes, and structures within the supply chain for planning, organising, coordinating, controlling, and leading for achieving the supply chain goals. In Industry 4.0, for the success of the supply chain, these constituent elements in the supply chain are digitalised [42]. This results in a business ecosystem wherein the participating organizations work to make joint optimisation to create successful delivery of products to the customers. The digitization of the supply chain further results in "big data" being generated within the supply chain systems, structures, and processes[43]. These big data are strategically used by the organization to manage the supply chain. Hence, the first type of normative pressure is when other organizations who are participating in the value creation process will exert pressure on organizations to adopt Industry 4.0 so that the digital transformation of the organization is possible. Industry 4.0 implementation is the joint optimisation of human and technical systems. The employees are, therefore, the key to the successful implementation of Industry 4.0. Employees by their qualification and experience in Industry 4.0 technologies can also exert pressure for implementation of Industry 4.0 in Indian Engineering Industry. The firms in the Indian Engineering Industry will also try to mimic other successful firms which have already implemented Industry 4.0. Thus, pressure will be created on firms which have not implemented Industry 4.0 to mimic other successful firms.

Industry 4.0 implementation can also be analysed from updated Institutional theory. The process of regulation is primarily of two types (a) inducement and (b) imposition. Inducement could be from other organizations who are in cooperative or competitive relationship to implement Industry4.0. Inducement from cooperative organizations would be to maintain the business standards, and there will be pressure on focal organizations to implement Industry 4.0. If the competitors have implemented Industry 4.0, there would be an active pressure exerted on the focal organizations to implement Industry 4.0. Inducement is also possible Government to implement Industry 4.0. The Government can act as a facilitator to implement Industry 4.0. National manufacturing policy, 2017 was launched as a push for organizations to implement Industry 4.0. It focusses that manufacturing organizations percentage share rise to $25 \%$. Centre for excellence in IT for Industry 4.0 is another initiative by the Government which will help firms to implement Industry 4.0. The national programme of Artificial intelligence launched by Government of India will provide a roadmap for implementing "Artificial Intelligencee" (AI) related programs in India. Another such measure launched by the Government is National Mission on Interdisciplinary Cyber-Physical Systems (NM-ICPS) which will be implemented by the Department of Science \& Technology (DST). Its mission is to develop a strong foundation in India towards CPS technologies[44, 45], SAMARTH Udyog Bharat 4.0 which is targeted towards making products for the global markets at competitive rates [12]. There have been no imposition measures so far by the Government of India to implement Industry 4.0 in Indian Engineering Industries. It is understandable as the Government wants to induce the organizations to implement Industry 4.0, considering the pros and cons in their respective firms, so that they can use these resources in a unique bundle to create competitive advantage.

The second process of institutionalising is validation and is the interaction between normative and mimetic pressure [24]. The Government of India is in the process of framing various rules or codes which will help the firms to implement Industry 4.0. The rules or codes will have to be designed taking into account a wide spectrum of stakeholders, ranging from new labour policies or acts to policy for IoT [46]. It will therefore require authorisation by concerned bodies before it becomes a rule or act. And in the meantime, firms implementing Industry 4.0 will also develop their codes or rules, which will assist in the implementation of Industry 4.0. The mimetic pressure from other co-operating and competing organizations will add pressure on the organizations to implement Industry 4.0 [34].

The third process of institutionalization is habitualising. When more and more firms in the Indian Engineering Industry will implement Industry 4.0, the implementation policies, rules, codes etc will be a habitual process. At a microlevel, when the new method of carrying out work after implementation of Industry 4.0, it will be 
done repetitively with minimal efforts. All the resistance towards Industry 4.0 will gradually thus melt off, as in the due course Industry 4.0 implementation will be a new normal. There would be bypassing of old cultural norms, beliefs, the old ways of carrying out work, decision making, old KPIs, managing stakeholders etc and a new Industry 4.0 system would be created. Though there would be new systems coming in due to the implementation of Industry 4.0, however, the organizational values and ethics will remain the same and it will be imprinted in the new organizational structure or processes which will be designed due to the implementation of Industry 4.0.

\subsection{Resources based Analysis of Indian Engineering Industry}

The resource-based view explains how organizations can create resources or capabilities to attain sustainable competitive advantages [28]. The resources are classified as human capital, physical capital, and organizational capital [31]. The resources were further extended to technological, financial, and reputational capital. Resources are something which a firm possesses, and it is made up of tangible or intangible resources. Tangible resources such as infrastructure and intangible resources such as organizational knowledge or organizational learning [47]. These tangible and intangible resources are combined and used to create a competitive advantage [31]. A study recommends "12 design principles" and "14 technology trends" as a central tenant of Industry 4.0[48].[48]. In another study, it is proposed 64 technologies which constitute Industry 4.0 [49]. These technologies can be used as a firm resource to attain competitive advantage. Employees play a major role in the implementation of Industry 4.0 in Indian Engineering Industry. The strength of a firm in terms of their employees having Industry 4.0 training, their experience in implementing Industry 4.0, the decision-making ability, judgment, business acumen etc will be human capital an organization [46] can use for competitive advantage. Industry 4.0 in Indian Engineering Industry will warrant implementation of new reporting structure, bigdata based planning, autonomous controlling, and coordination, within the organization as well as within the value chains. This will further create organizational capital for the firms implementing Industry 4.0. Industry 4.0 in Indian Engineering Industry implementation results in "vertical", "horizontal", and "end-to-end" integration. The three types of integration found in Industry 4.0 are (a) "Horizontal integration", (b) the "vertical integration" , and c) "end-to-end integration" [50]. The "vertical integration" is the digital connectivity of all functional department within an organization, that is included in the value chain of producing the product [51]. To cite an example activity such as marketing, design, engineering etc. are all integrated through a technological platform which will enable ease in distributing resources in the company effectively and efficiently to meet the value chain of product or service. "Horizontal integration" occurs when a company is digitally integrated with its partners, suppliers, distributors, and other elements which are external to the organization and are taking part in the value-creation process. In end-to-end integration, digital integration has been designed around the different phases of the product life cycle, such as introduction, growth, maturity, and decline. It begins with the machine to machine integration on the shop floor. The second step is customers are integrated with the organization e.g. manufacturing system and thirdly product to service concept is foreseen based on which the organization can monitor the products resulting in new business models Chen, 2017; Sony, 2018 \& Sony \& Naik, 2019 [3, 6, 51]. The modern factory is thus becoming more complex and intelligent due to big data analytics, machine learning and cloud computing with the advent of Industry 4.0 Saldivar et al., 2015 [52]. The type of integration creates a physical resource for the firm, which they can use it strategically to create a competitive advantage. The initial cost of implementation of Industry 4.0 is high but over years, due to reduction in operating cost, it will break even and in the due course earn above-normal profits [43], leading to financial resources which the organization can use it for competitive advantage. Industry 4.0 implementation in Indian Engineering Industry will improve the reputation of the firm because the products will be safe, high quality, and low cost. The improved reputation of the firm can also be used as a tool for competitive advantage.

\section{AN INTEGRATIVE MODEL TO EXPLAIN IMPLEMENTATION OF INDUSTRY 4.0 IN INDIAN ENGINEERING INDUSTRY :}


The institutional theory makes the assumption that organizations try to comply with external formal and informal pressures[25]. The focus of the theory is to sustain the relationship between organization and environment. The theory further guides on establishing structures and guiding social behaviours. The institutions "rules of the game" are formally defined as "humanly devised constraints that structure human interaction". They are basic rules which are formal, informal and codes. The formal constraints are "rules, laws and constitutions". Informal constraints are "norms of behaviour, conventions, and codes of conduct" and codes are codes of conduct. The formal and informal constraints help the institutions to deal with uncertainty and reduce transaction cost. Firms are regarded as rational actors and they comply with formal and informal constraints set by the institutions to attain organizational goals and objectives. Therefore, institutions exert considerable influence in organizational decisions such as the implementation of Industry 4.0 in Indian Engineering Industry. The three types of pressures faced by the organizations to implement Industry 4.0 are normative, coercive, and mimetic. These pressures influence the top management in an organization to implement Industry 4.0. The implementation of Industry 4.0 will result in the creation of physical, human, organizational, technological, financial and reputation capital for the firm. These capitals are levers which will help them to create competitive advantage. Figure 1 depicts the integrated perspective of Institutional Theory and Resource-based theory to create a competitive advantage.

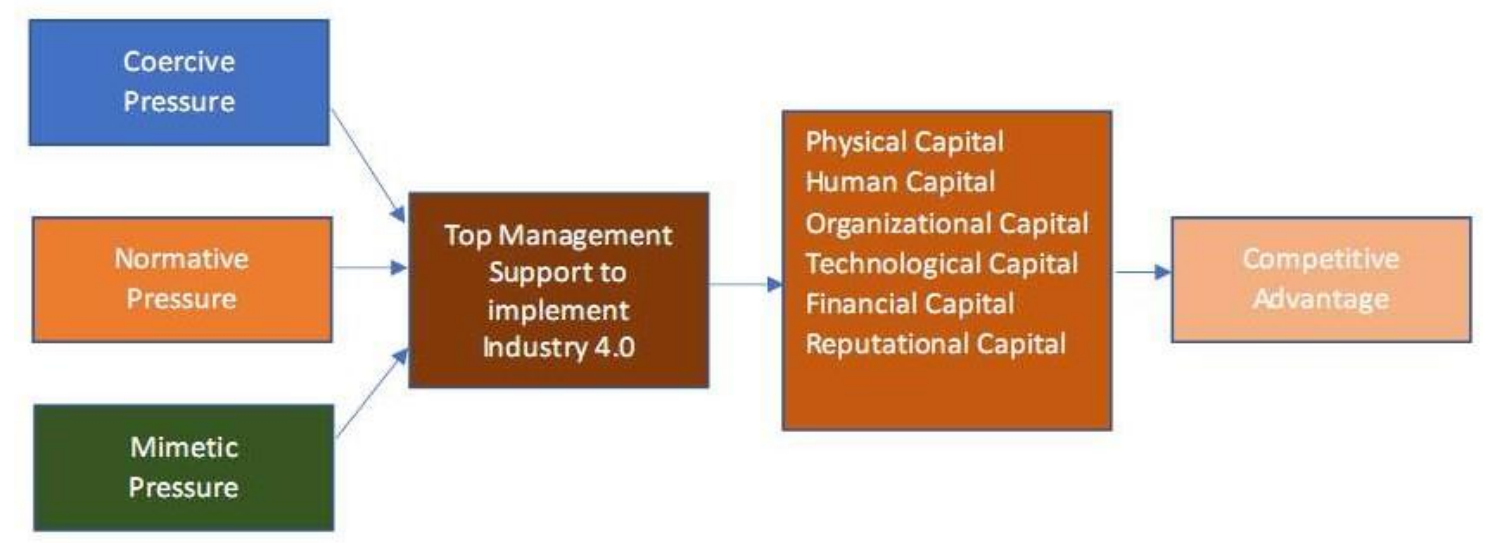

Fig. 1: Integrative Model Industry 4.0 implementation using institutional and resource-based theory

\section{DISCUSSION :}

Industry 4.0 implementation in Indian Engineering Industry can make it agile, efficient, effective, and competitive in the global markets[36]. To understand the dynamics of Industry 4.0 implementation decisions by the firms in Indian Engineering Industry, this study uses institutional theory and resource-based theory. The three types of pressures faced by the organization to implement Industry 4.0 are normative, coercive, and mimetic. The coercive pressure can be exerted on the top management of the focal organization by other organizations which it does business with [20]. The higher the power distance, the focal organization would be coerced to implement Industry 4.0. The Indian Engineering Industry is depended on various organizations and if those organizations implement Industry 4.0, the focal organization will be forced to implement the same. Normative pressures are exerted on organizations because of professionalization [20]. The normative pressures in an organization may also arise from suppliers, customer and professional organization[53]. This occurs when norms of adoption have emerged in its environment. In Indian Engineering Industry there will be communication from superior organization to implement Industry 4.0. Similarly, from downstream organizations or customers, there will be demand on the Indian Engineering Industry for high-quality smart products. This is because smart products are the new norm in the Industry [54] and every professional association or customer wants to affiliate with the organization which produces smart products. Mimetic pressures would be exerted from peer organizations [20]. The firm usually imitates successful firms in terms 
of choices in various aspects of business[53], to be a legitimate organization. Therefore, these three types of forces will exert pressure on top management to initiate action to implement Industry 4.0[55]. The decision of the top management to implement Industry 4.0 will depend on the intensity of the three types of pressures and organizational objectives. Higher the pressure, the commitment exerted by the top management towards Industry 4.0 implementation would be high. The commitment of top management will result in building firm resources [56]. Industry 4.0 results in the building of the physical capital of the organization. Each firm within the Indian Engineering Industry will be able to create a unique sustainable competitive advantage using the bundle of six resources. Each firm, therefore, in the Indian Engineering Industry will use physical capital to create competitive advantage in domestic and global markets. We assume here that firms after implementing Industry 4.0 within the Indian Engineering Industry will be able to create heterogeneity concerning the approach the six resources will be developed within the organization. The physical capital after implementation of Industry 4.0 would be in terms of the smart factory. It envisages a concept of total automation by using technologies such as IoT, CPS and cloud computing [57, 58]. The firms would differ on the degree of automation and the number of automation resources at the disposal of the firm. The second resource would be human capital. This will depend on the employee's experience, judgement, and intelligence for implementation of Industry 4.0[4, 46]. All firm will not have equal access to all employees with these three types of characteristics, therefore, there would be the heterogeneity of firm resources and capability even within the same Indian Engineering Industry. The organizational capital resources are unique after implementation of Industry 4.0. A firm can choose a different organizational structure, line of communication, planning, organizing, controlling, coordinating, and leading strategies [59]. Therefore, firms will be able to uniquely place themselves within the Indian Engineering Industry. This can create a competitive advantage for the firm. Industry 4.0 is a technologically complex system of automation[6]. Therefore, the phases of technology management within every firm such as of R\&D, accent, maturity and decline of each of the 64 technologies has to be managed by the firm [49]. The capabilities of firms to manage the 64 technologies of Industry 4.0 will defer among firms even within the same Indian Engineering Industry. Therefore, Industry 4.0 can create competitive dimension using the technological resource. The initial capital for implementing Industry 4.0 is very high, however, in the due course due to a reduction in operating cost, it will break even [36]. There will also be revenue maximisation because now the firm will be able to capture larger markets. Hence, the financial capital of the firms can be used to achieve competitive advantage. The reputational capital of the firm will increase due to the implementation of Industry 4.0 [60, 61]. The dimensions along which the firm reputation will increase will vary across the firms in the Indian Engineering Industry are product and service reputation, customer service reputation, intellectual resource reputation and so on. Therefore, the firms will be able to use reputational resources for competitive advantage. To create a sustained competitive advantage in Indian Engineering Industry, the six type of resources after implementing Industry 4.0, should have the following characteristics (a) It must add value to the firm (b) It must be rare or unique (c) It must be imperfectly imitable (d) The resource cannot be substitutable [28].

\section{CONCLUSION :}

Industry 4.0 implementation in Indian Engineering Industry can make it agile, efficient, effective, and competitive in the global markets. However, Industry 4.0 is making gradual inroads in the Indian Engineering Industry. To understand the dynamics of Industry 4.0 implementation decisions by the firms in Indian Engineering Industry, this study uses institutional theory and resource-based theory to study the phenomenon. An integrative model is developed to explain the dynamics of Industry 4.0 implementation in Indian Engineering Industry. This is the first paper to analyse the dynamics of Industry 4.0 implementation in the Indian Engineering Industry. These conceptual analyses may further be extended into an empirical study to confirm the integrative model developed. In addition, qualitative studies will also help to understand the decision making to implement Industry 4.0 in the Indian Engineering Industry.

\section{REFERENCES :}

[1] Büchi, G., Cugno, M., \& Castagnoli, R. (2020). Smart factory performance and Industry 4.0. 
Technological Forecasting and Social Change, 150, 119790.

[2] Brettel, M., Friederichsen, N., Keller, M., \& Rosenberg, M. (2014). How virtualization, decentralization and network building change the manufacturing landscape: An Industry 4.0 Perspective. International Journal of Mechanical, Industrial Science and Engineering, 8(1), 37-44.

[3] Sony, M., \& Naik, S. (2019). Key ingredients for evaluating Industry 4.0 readiness for organizations: a literature review. Benchmarking: An International Journal, 27(7), 2213-2232. https://doi.org/https://doi.org/10.1108/ BIJ-09-2018-0284

[4] Frey, C. B., \& Osborne, M. A. (2017). The future of employment: how susceptible are jobs to computerisation? Technological forecasting and social change, 114, 254-280.

[5] Wang, S., Wan, J., Li, D., \& Zhang, C. (2016). Implementing smart factory of industrie 4.0: an outlook. International Journal of Distributed Sensor Networks, 12(1), 3159805.

[6] Sony, M. (2018). Industry 4.0 and lean management: a proposed integration model and research propositions. Production \& Manufacturing Research, 6(1), 416-432.

[7] Beier, G., Niehoff, S., \& Xue, B. (2018). More sustainability in industry through industrial internet of things? Applied sciences, 8(2), 219.

[8] Ghobakhloo, M. (2020). Industry 4.0, digitization, and opportunities for sustainability. Journal of Cleaner Production, 252, 119869.

[9] Tortorella, G. L., \& Fettermann, D. (2018). Implementation of Industry 4.0 and lean production in Brazilian manufacturing companies. International Journal of Production Research, 56(8), 2975-2987.

[10] Molly, R. (2020). Industry 4.0: A great future. Manufacturing Today India. Retrieved from https://www.manufacturingtodayindia.com/sectors/6089-industry-40-a-great-future

[11] UNIDO. (2020). Industrial Development Report 2020. Industrializing in the digital age. Retrieved from https://www.unido.org/resources-publications-flagship-publications-industrial-development-reportseries/idr2020

[12] SAMARTH Udyog Bharat 4.0. (2019). Industry 4.0 : SAMARTH Udyog Bharat 4.0. Retrieved from https://www.samarthudyog-i40.in/about-i40\#

[13] EEPC. (2020). Indian Engineering Electrifying Growth. Retrieved from http://www.eepcindia.org/download/IndianEngineeringBrochure-200819124444.pdf

[14] Oztemel, E., \& Gursev, S. (2020). Literature review of Industry 4.0 and related technologies. Journal of Intelligent Manufacturing, 31(1), 127-182.

[15] Peng, M. W., Sun, S. L., Pinkham, B., \& Chen, H. (2009). The institution-based view as a third leg for a strategy tripod. Academy of Management Perspectives, 23(3), 63-81.

[16] Zukin, S., DiMaggio, P., \& DiMaggio, P. (1990). Structures of capital: The social organization of the economy. CUP Archive.

[17] Oliver, C. (1997). Sustainable competitive advantage: combining institutional and resource- based views. Strategic management journal, 18(9), 697-713.

[18] Ciftci, I., Tatoglu, E., Wood, G., Demirbag, M., \& Zaim, S. (2019). Corporate governance and firm performance in emerging markets: Evidence from Turkey. International Business Review, 28(1), 90103.

[19] Demirbag, M., Glaister, K. W., \& Tatoglu, E. (2007). Institutional and transaction cost influences on MNEs' ownership strategies of their affiliates: Evidence from an emerging market. Journal of World 
Business, 42(4), 418-434.

[20] DiMaggio, P., \& Powell, W. W. (1983). The iron cage revisited: Collective rationality and institutional isomorphism in organizational fields. American sociological review, 48(2), 147-160.

[21] Scott, W. R. (2013). Institutions and organizations: Ideas, interests, and identities. Sage publications.

[22] Dubey, R., Gunasekaran, A., Childe, S. J., Blome, C., \& Papadopoulos, T. (2019). Big data and predictive analytics and manufacturing performance: integrating institutional theory, resource- based view and big data culture. British Journal of Management, 30(2), 341-361.

[23] Srinivasan, R., \& Swink, M. (2018). An investigation of visibility and flexibility as complements to supply chain analytics: An organizational information processing theory perspective. Production and Operations Management, 27(10), 1849-1867.

[24] Grewal, R., \& Dharwadkar, R. (2002). The role of the institutional environment in marketing channels. Journal of marketing, 66(3), 82-97.

[25] Oliver, C. (1991). Strategic responses to institutional processes. Academy of management review, 16(1), 145-179.

[26] Stern, L. W., El-Ansary, A. I., \& Coughlan, A. T. (1996). Marketing Channels Prentice-Hall. Upper Saddle River, NJ.

[27] Khanchanapong, T., Prajogo, D., Sohal, A. S., Cooper, B. K., Yeung, A. C. L., \& Cheng, T. C. E. (2014). The unique and complementary effects of manufacturing technologies and lean practices on manufacturing operational performance. International Journal of Production Economics, 153, 191-203.

[28] Barney, J. (1991). Firm resources and sustained competitive advantage. Journal of management, 17(1), 99-120.

[29] Kumar, M., \& Rodrigues, V. S. (2020). Synergetic effect of lean and green on innovation: A resourcebased perspective. International Journal of Production Economics, 219, 469-479.

[30] Barney, J. B., \& Clark, D. N. (2007). Resource-based theory: Creating and sustaining competitive advantage. Oxford University Press on Demand.

[31] Grant, R. M. (1991). The resource-based theory of competitive advantage: implications for strategy formulation. California management review, 33(3), 114-135.

[32] Ulrich, D., Brockbank, W., Yeung, A. K., \& Lake, D. G. (1995). Human resource competencies: An empirical assessment. Human resource management, 34(4), 473-495.

[33] Teece, D. J. (1986). Firm boundaries, technological innovation, and strategic management. The economics of strategic planning, 187-199.

[34] Gupta, S., Modgil, S., Gunasekaran, A., \& Bag, S. (2020). Dynamic capabilities and institutional theories for Industry 4.0 and digital supply chain. In Supply Chain Forum: An International Journal (pp. 1-19). Taylor \& Francis.

[35] Koryak, O., Mole, K. F., Lockett, A., Hayton, J. C., Ucbasaran, D., \& Hodgkinson, G. P. (2015). Entrepreneurial leadership, capabilities and firm growth. International Small Business Journal, 33(1), 89-105.

[36] Sony, M., \& Aithal, P. S. (2020). Transforming Indian Engineering Industries through Industry 4.0: An Integrative Conceptual Analysis. International Journal of Applied Engineering and Management Letters, 4(2), 111-123. https://doi.org/http://doi.org/10.5281/zenodo.4008834.

[37] Papachashvili, N. (2018). Industry 4.0 and its impact on the international trade. 
[38] Li, C. H., \& Lau, H. K. (2017). A critical review of product safety in Industry 4.0 applications. In 2017 IEEE International Conference on Industrial Engineering and Engineering Management (IEEM) (pp. 1661-1665). IEEE.

[39] Bragança, S., Costa, E., Castellucci, I., \& Arezes, P. M. (2019). A brief overview of the use of collaborative robots in industry 4.0: human role and safety. In Occupational and Environmental Safety and Health (pp. 641-650). Springer.

[40] Magdalena, G. (2016). Industry 4.0 and sustainability impacts: Critical discussion of sustainability aspects with a special focus on future of work and ecological consequences. Annals of the Faculty of Engineering Hunedoara - International Journal of Engineering, 14(2), 131-136.

[41] Korpela, K., Hallikas, J., \& Dahlberg, T. (2017). Digital supply chain transformation toward blockchain integration. In proceedings of the 50th Hawaii international conference on system sciences.

[42] Lichtblau, K., Stich, V., Bertenrath, R., Blum, M., Bleider, M., Millack, A., ... Schroter, M. (2015). Industrie 4.0-Readiness. Impuls-Stiftung des VDMA Aachen-Köln, 52(1), 1-77.

[43] Sony, M., \& Naik, S. (2019). Ten Lessons for managers while implementing Industry 4.0. IEEE Engineering Management Review, 47(2), 45-52.

[44] NM-ICPS. (2019). National Mission on Interdisciplinary Cyber Physical Systems. Science and Engineering Research Board. Retrieved from http://www.serb.gov.in/nm-icps.php

[45] Jadhav, V. V., \& Mahadeokar, R. (2019). The Fourth Industrial Revolution (I4. 0) in India: Challenges \& Opportunities. Management, 105-109.

[46] Sony, M., \& Aithal, P. S. (2020). Practical Lessons for Engineers to adapt towards Industry 4.0. International Journal of Case Studies in Business, IT, and Education, 4(2), 86-97. https://doi.org/http://doi.org/10.5281/zenodo.4008814.

[47] Größler, A., \& Grübner, A. (2006). An empirical model of the relationships between manufacturing capabilities. International Journal of Operations \& Production Management.

[48] Ghobakhloo, M. (2018). The future of manufacturing industry: a strategic roadmap toward Industry 4.0. Journal of Manufacturing Technology Management, 29(6), 910-936.

[49] Klingenberg, C. O., Borges, M. A. V., \& Antunes Jr, J. A. V. (2019). Industry 4.0 as a data-driven paradigm: a systematic literature review on technologies. Journal of Manufacturing Technology Management.

[50] Kagermann, H., Helbig, J., Hellinger, A., \& Wahlster, W. (2013). Recommendations for implementing the strategic initiative INDUSTRIE 4.0: Securing the future of German manufacturing industry; final report of the Industrie 4.0 Working Group. Forschungsunion.

[51] Chen, Y. (2017). Integrated and intelligent manufacturing: Perspectives and enablers. Engineering, 3(5), 588-595.

[52] Saldivar, A. A. F., Li, Y., Chen, W., Zhan, Z., Zhang, J., \& Chen, L. Y. (2015). Industry 4.0 with cyberphysical integration: A design and manufacture perspective. In Automation and computing (icac), 2015 21 st international conference on (pp. 1-6). IEEE.

[53] Teo, H.-H., Wei, K. K., \& Benbasat, I. (2003). Predicting intention to adopt interorganizational linkages: An institutional perspective. MIS quarterly, 19-49.

[54] Mani, Z., \& Chouk, I. (2017). Drivers of consumers' resistance to smart products. Journal of Marketing Management, 33(1-2), 76-97. 
[55] Zheng, D., Chen, J., Huang, L., \& Zhang, C. (2013). E-government adoption in public administration organizations: integrating institutional theory perspective and resource-based view. European Journal of Information Systems, 22(2), 221-234.

[56] Singh, S. K., Gupta, S., Busso, D., \& Kamboj, S. (2019). Top management knowledge value, knowledge sharing practices, open innovation and organizational performance. Journal of Business Research.

[57] Burke, R., Mussomeli, A., Laaper, S., Hartigan, M., \& Sniderman, B. (2017). The smart factory: Responsive, adaptive, connected manufacturing. Deloitte Insights, August, 31.

[58] Sjödin, D. R., Parida, V., Leksell, M., \& Petrovic, A. (2018). Smart Factory Implementation and Process Innovation: A Preliminary Maturity Model for Leveraging Digitalization in Manufacturing Moving to smart factories presents specific challenges that can be addressed through a structured approach focused on people, . Research-Technology Management, 61(5), 22-31.

[59] Sony, M. (2019). Lean Six Sigma Implementation Framework Using Resource-Based Theory Approach: An Integrative Literature Review. In Optimizing Current Strategies and Applications in Industrial Engineering (pp. 287-304). IGI Global.

[60] Gilchrist, A. (2016). Introducing Industry 4.0. In Industry 4.0 (pp. 195-215). Springer.

[61] Sony M. and Aithal, P. S. (2020). Developing an Industry 4.0 Readiness Model for Indian Engineering Industries. International Journal of Management, Technology, and Social Sciences (IJMTS), 5(2), 141153.

[62] Sony M. and Aithal, P. S. (2020). Design of "Industry 4.0 readiness model" for Indian Engineering Industry: Empirical Validation Using Grounded Theory Methodology. International Journal of Applied Engineering and Management Letters (IJAEML), 4(2), 124-137. 